\title{
The Reinforcement of Health Logistic in Mawar Iteng Program as a Strategy of Improving Human Development Index in Pemalang Regency
}

\author{
Johan Bhimo Sukoco ${ }^{1}$, Luluk Fauziah ${ }^{2}$, Suwandi $^{3}$, Wildan Aghits Attoriq ${ }^{4}$ \\ \{johanbhimo@lecturer.undip.ac.id ${ }^{1}$, lulukfauziah@lecturer.undip.ac.id², suwandi@lecturer.undip.ac.id ${ }^{3}$, \\ aghitswildan@gmail.com ${ }^{4}$ \} \\ Universitas Diponegoro, Indonesia ${ }^{1,2,3,4}$
}

\begin{abstract}
Mawar Iteng program is a health program to mother and infant in Pemalang Regency. This program is acronym of Mak'e waras bayine kentheng, meaning mother is healthy during giving birth and her infant is also safe. This program is intended to reduce Maternal Mortality Rate (MMR) and Infant Mortality Rate (IMR). This successful program should be supported by adequate health logistic providing. This research focused on studying health logistic supply, viewed from the presence of supporting facilities and its distribution. This research employed descriptive qualitative method. Techniques of collecting data used were structured interview, non-participatory observation, and document analysis. Interactive analysis model was used as technique of analyzing data, while data validation was carried out using method triangulation. The result of research showed that this program has not provided health logistic optimally yet. It could be seen from the inadequate availability of ambulance. This condition should get much attention from the government, recalling that the location of main Puskesmas is far from the subsidiary Puskesmas or other medical centers. Ideally, the reinforcement of health logistic is required, particularly in providing an adequate mobile public health center (Puskesmas Keliling).
\end{abstract}

Keywords: Logistic, Health, Strategic, Mawar Iteng.

\section{Introduction}

Human development index (HDI) of Pemalang Regency in 2008 was very ironic. HDI in Pemalang Regency in the year was on the lowest rate compared with other regencies or cities in Central Province. The score obtained by Pemalang Regency is only 65.67, lower than that of other 35 regencies or cities. Although this rate increases compared with that in previous year, 65.04 in 2017, but this score is ironically still lower than that of Brebes Regency on the lowest position previously, 65.68 .

Widodo et al [1] stated that in improving human development, there are at least two sectors to consider by government in relation to the attempt of expanding the population's opportunity of achieving reasonable life, education and health sectors.

Furthermore, Maulana and Bowo [2] suggested that a region's successful development can be measured using some parameters, the most popular of which is Human Development Index (HDI). 
In 2018, BPS (Central Bureau of Statistic)'s data shows that Maternal Mortality Rate (MMR) decreased compared with that in 2017, 100 per 100,000 live birth compared with 66.94 per 100,000 live birth in 2018. Nevertheless, maternal mortality quantity is still considered as high, 17 deaths in 2018 (Pemalang Regency's Health Office, 2018).

This high Maternal Mortality Rate encourages the government in Pemalang Regency to develop a program in the attempt of suppressing the rate, by means of Mawar Iteng program. This program is acronym of Mak'e waras bayine kentheng, meaning mother is healthy during giving birth and her infant is also safe. This program is intended to reduce Maternal Mortality Rate (MMR) and Infant Mortality Rate (IMR), constituting the components indicating life expectancy age having implication to the increased Human Development Index (HDI) of Pemalang Regency.

This research focused on studying the health logistic supply viewed from the available facilities supporting the program, and its distribution. It is associated with the reinforcement of health logistics in Mawar Iteng program in Pemalang Regency; an adequate logistic supply is expected to encourage the successful program thereby leading to higher HDI.

Few studies have been conducted on health logistic. However, those studies largely addressed health logistic in relation to medicine logistic management and health equipment procurement [3][4][5]. Satrianegara et al [3] studied the medicine logistic management in pharmacy installation of Lanto Daeng Regional Hospital, Pasewang, Jeneponto Regency. Kenedi et al [4] analyzed the procurement of health equipment's in Padang Pariaman Regional Hospital. Renaldi and Nanda [5] studied the management of medicine management in Puskesmas Limapuluh, Pekanbaru City.

These studies have studied health logistic in relation to medicine logistic management and health equipment procurement. These studies are beneficial in studying health logistic generally. However, only few studies have been conducted specifically on health logistic associated with a governmental program, particularly concerning the decrease of Maternal Mortality Rate (MMR) and Human Development Index (HDI). Considering some problems aforementioned, the author is interested in conducting a study entitled "The Reinforcement of Health Logistic in Mawar Iteng program as A Strategy of Improving Human Development Index in Pemalang Regency".

\section{Research Method}

This study was a descriptive research with qualitative method. This research described the reinforcement of health logistic in Mawar Iteng Program as a strategy to improving Human Development Index (HDI) in Pemalang Regency. This research was conducted in Pemalang Regency, Central Java, Indonesia from July to August 2019.

The target/subject of current research was Health Department, constituting the one responsible for health affairs in Pemalang Regency, and some health service units such as Puskesmas with higher maternal mortality rate. On the other hand, Puskesmas was also considered as successfully suppressing Maternal Mortality Rate in Pemalang Regency.

The author employed non-structured interview, non-participatory observation, and document study as techniques of collecting data. Non-structured interview was conducted to explore more the informants' response. Non-participatory observation was conducted by means of observing the condition of research site. Meanwhile, document study was conducted to 
analyze documents related to the reinforcement of health logistic sector in Mawar Iteng Program as a strategy of improving Human Development Index (HDI) in Pemalang Regency.

Technique of analyzing data used in this research was Miles and Huberman's interactive model of analysis. This analysis was conducted by considering 3 (three) basic components: data reduction, data display, and conclusion drawing as well as verification.

\section{Result and Discussion}

\subsection{Human Development Index Concept}

UNDP has developed HDI composite index based on 3 (three) indicators: life expectancy at birth, adult literacy rate and mean years of schooling, and purchasing power parity. Indicator of life expectancy at birth represents health aspect. Indicators of adult literacy rate and mean years of schooling represent education aspect, while indicator of purchasing power parity is intended to measure economic aspect/standard of life [6][7].

This human development is not only measured from gross domestic product (GDP). Widodo et al [1] mentioned that there are at least 2 (two) sectors to consider by government in relation to the attempt of expanding its population's opportunity of achieving proper life. They are: education and health.

\subsection{Concept of Logistic Management}

Rizky [8] defined logistic management as a strategic management process related to the transfer and storage of product, spare part, and finished product from supplier to customer. Furthermore, Febriawati [9] stated that hospital is a business unit operating a variety of production activities. Meanwhile, hospital production activity includes service production, so that the logistic activity here is defined to pertain to the management of material, goods, and equipment supply necessary in the service production attempt.

Lukas and Sari [10] stated that logistic management is anything or material goods needed physically (tangible), and used for organizing main or supporting activities (administration). In line with this, Aditama suggested that logistic management is a science or art and process of planning and deciding the needs, from procurement, storage, distribution, and maintenance, to removal of material or tools. Logistic management is basic supporting element to an administration system closely interrelated to other elements of administration system in development implementation.

\subsection{Discussion}

Some studies related to health logistic have been conducted as well by other authors. Satrianegara et al [3] studied the management of medicine logistic in pharmacy installation of Lanto Daeng Regional Hospital, Pasewang, Janeponto Regency. The result of research showed that planning, procurement based on tender and direct purchasing, repeated order occur when the medicine stock is empty in distributor.

Kenedi, et al [4] analyzed the procurement of health equipment in Padang Pariaman Regional Hospital and concluded that the procurement of health instrument is the hospital's attempt of managing logistic related to the fulfillment of health equipment need in improving 
the service quality. Renaldi and Nanda [5] studied the management of medicine in Puskesmas Limapuluh, Pekanbaru City. They concluded that the management of medicines in the locus of research has not been consistent with FIFO in which the product coming first will be released first (First In First Out), and FEFO (First Expired First Out) rules.

Some previous studies have studied the health logistic related to the management of medicine logistic and the procurement of health equipment. These studies are very beneficial to the author in studying health logistic generally. However, only few studies have investigated specifically the health logistic related to a governmental program particularly concerning the decrease of Maternal Mortality Rate (MMR) and Human Development Index. This research focused on studying the supply of health logistic, viewed from the availability of facilities supporting the program and its distribution.

The quantity of live birth in Pemalang Regency was 25,396 births in 2018, distributed in 25 Public Health Centers (Puskesmas). In the same year, the quantity of maternal death was 17 cases. The largest death quantity occurred in postpartum women, 11 deaths, followed with 4 deaths in pregnant women, and 2 deaths in parturient women.

The result of research showed that age interval of 20-34 years is the one with highest mortality quantity to a woman. There are 7 death cases for age group $>35$ years, and 2 death cases for $<20$-year age group. The largest quantity of maternal mortality occurs in Klareyan region, 3 cases. This figure is followed with 2 maternal mortality cases in Belik, Kebondalem, and Mojo respectively.

Compared with other regions in Central Java, Pemalang Regency occupies the 9th position. This rank is actually better, compared with Kendal and Banyumas Regencies, 18 maternal mortality cases. This figure is followed with Semarang City 19 cases, Batang Regency 20 cases, Cilacap 22 cases, Demak Regency 23 cases, Brebes 30 cases, and Grobogan Regency 31 cases.

Figure 1 shows the comparison of Maternal Mortality Rate (MMR) between Pemalang Regency and other regions in Central Java.

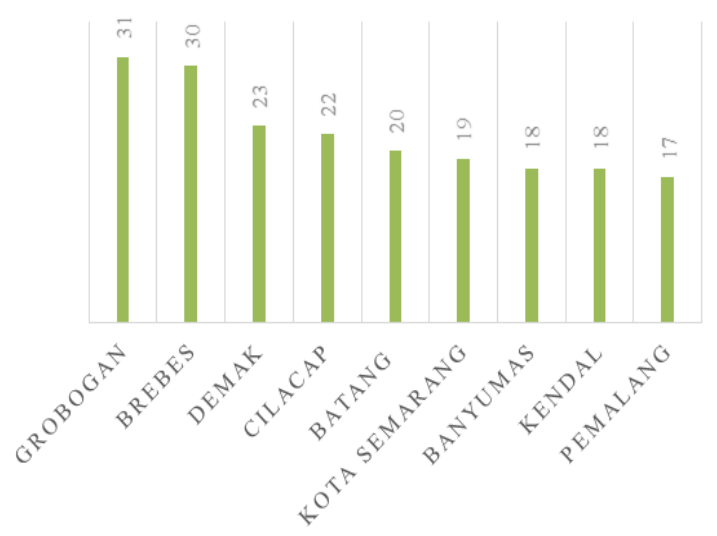

Fig. 1. Comparison of MMR between Pemalang Regency and other Regions (Source: Central Java's Central Bureau of Statistic 2019, processed).

Health logistic in Pemalang Regency is fulfilled by Public Health Centers (Puskesmas) distributed in some regions. There were 25 Puskesmas in Pemalang Regency in 2018. The ratio of Puskesmas number in Pemalang Regency, compared with ideal concept of Puskesmas number per 30,000 populations, is 0.58 . It means that this figure has not been ideal yet. Compared with the quantity of populations in Pemalang Regency, the ideal number of 
Puskesmas is 43. Therefore, the coverage of healthcare service and the health logistic distribution are conducted using Puskesmas Pembantu (Pustu or subsidiary Puskesmas) and Puskermas Keliling (Pusling or mobile puskesmas) concepts.

Health logistic in Pemalang Regency is supplied by these Puskesmas, Pustu, and Pusling. There have been 25 Puskesmas, 62 Pustu, and 47 Pusling in Pemalang Regency up to 2018. The data of Puskesmas in Pemalang Regency can be seen in Table 1.

Table 1. Quantity of Puskesmas, Pustu and Pusling in Pemalang Regency during 2015-2018

\begin{tabular}{|l|c|c|c|c|}
\hline \multicolumn{1}{|c|}{ Health Facilities } & 2015 & 2016 & 2017 & 2018 \\
\hline Puskesmas & 22 & 22 & 22 & 25 \\
\hline Pustu & 65 & 65 & 65 & 62 \\
\hline Pusling & 47 & 47 & 47 & 47 \\
\hline
\end{tabular}

Source: Health Profile of Pemalang Regency in 2018.

The distribution of health logistic in Pemalang Regency is also reinforced with the presence of integrated service post (Posyandu), integrated building post (Posbindu), and village health center (Puskesdes). Pemalang Regency has had 141 Puskesdes, 1.192 Posyandu, and 76 Posbindu up to 2018. Health logistic is also reinforced by Posbindu, the quantity of which increases significantly over years. There were only 10 Posbindu in 2015, increasing to 23 in 2016, 35 in 2017, and 76 in 2018. Data of facilities supporting health logistic is presented in table 2 .

Table 2. Number of Puskesdes, Posyandu and Posbindu in Pemalang Regency during 2015-2018

\begin{tabular}{|l|c|c|c|c|}
\hline \multicolumn{1}{|c|}{ Public Health Facilities } & 2015 & 2016 & 2017 & 2018 \\
\hline Puskesdes & 141 & 141 & 141 & 141 \\
\hline Posyandu & 1,180 & 1,189 & 1,192 & 1,192 \\
\hline Posbindu & 10 & 23 & 35 & 76 \\
\hline
\end{tabular}

Source: Health Profile of Pemalang Regency, 2018.

Health Logistic in Pemalang Regency is reinforced with the presence of 8 hospitals. There are 7 general hospitals and 1 special Hospital in Pemalang Regency. Out of 7 hospitals, 1 belongs to Regency Government, and the other 6 belong to private. For more detail, see table below.

Table 3. Hospitals in Pemalang Regency

\begin{tabular}{|c|l|c|c|c|c|c|c|c|}
\hline No & $\begin{array}{c}\text { Health } \\
\text { Facilities }\end{array}$ & $\begin{array}{c}\text { Ministry } \\
\text { of Health }\end{array}$ & $\begin{array}{c}\text { Prov. } \\
\text { Gov. }\end{array}$ & $\begin{array}{c}\text { Regency } \\
\text { Gov. }\end{array}$ & $\begin{array}{c}\text { TNI/ } \\
\text { POLRI }\end{array}$ & $\begin{array}{c}\text { State-Owned } \\
\text { Enterprise }\end{array}$ & Private & Total \\
\hline 1 & $\begin{array}{l}\text { General } \\
\text { Hospital }\end{array}$ & 0 & 0 & 1 & 0 & 0 & 6 & 7 \\
\hline 2 & $\begin{array}{l}\text { Special } \\
\text { Hospital }\end{array}$ & 0 & 0 & 0 & 0 & 0 & 1 & 1 \\
\hline
\end{tabular}

Source: Health Profile of Pemalang Regency, 2018.

In addition, health logistic in Pemalang Regency is reinforced by 4 inpatient Public Health Center (Puskesmas Rawat Inap), belonging to Regency Government. This Puskesmas has 78 beds. Furthermore, Pemalang Regency has 47 units of non-inpatient Public Health Center (Puskesmas Non-Rawat Inap) that can help distribute health logistic. There are 65 units of subsidiary public health center (Puskesmas Pembantu). The data is presented in Table 4. 
Table 4. Puskesmas and its Network

\begin{tabular}{|c|l|c|c|c|c|c|c|c|}
\hline No & \multicolumn{1}{|c|}{ Health Facilities } & $\begin{array}{c}\text { Ministry } \\
\text { of Health }\end{array}$ & $\begin{array}{c}\text { Prov. } \\
\text { Gov. }\end{array}$ & $\begin{array}{c}\text { Regency } \\
\text { Gov. }\end{array}$ & $\begin{array}{c}\text { TNI/ } \\
\text { POLRI }\end{array}$ & $\begin{array}{c}\text { State-Owned } \\
\text { Enterprise }\end{array}$ & Private & Total \\
\hline 1 & $\begin{array}{l}\text { Inpatient Public } \\
\text { Health Center }\end{array}$ & 0 & 0 & 4 & 0 & 0 & 0 & 4 \\
\hline & - Number of beds & 0 & 0 & 78 & 0 & 0 & 0 & 78 \\
\hline 2 & $\begin{array}{l}\text { Non-inpatient Public } \\
\text { Health Center }\end{array}$ & 0 & 0 & 18 & 0 & 0 & 0 & 18 \\
\hline 3 & $\begin{array}{l}\text { 4-wheel mobile public } \\
\text { health center }\end{array}$ & 0 & 0 & 47 & 0 & 0 & 0 & 47 \\
\hline 4 & $\begin{array}{l}\text { Subsidiary Public } \\
\text { Health Center }\end{array}$ & 0 & 0 & 65 & 0 & 0 & 0 & 65 \\
\hline
\end{tabular}

Source: Health Profile of Pemalang Regency, 2018.

In providing health logistic, Pemalang Regency's Government is reinforced with the presence of 36 Medical Centers/Clinics. Out of 36 Medical Centers/Clinics existing, 34 units belong to private and 2 to TNI/POLRI. Meanwhile, there are 151 general practitioners practicing individually in this region. Pemalang Regency has not documented Maternal House, Medical Practice Joint Venture, and Traditional Medical Practice. It can be seen in Table 5.

Table 5. Other Health Facilities

\begin{tabular}{|c|l|c|c|c|c|c|c|c|}
\hline No & \multicolumn{1}{|c|}{ Health Facilities } & $\begin{array}{c}\text { Ministry of } \\
\text { Health }\end{array}$ & $\begin{array}{c}\text { Prov. } \\
\text { Gov. }\end{array}$ & $\begin{array}{c}\text { Regency } \\
\text { Gov. }\end{array}$ & $\begin{array}{c}\text { TNI/ } \\
\text { POLRI }\end{array}$ & $\begin{array}{c}\text { State-Owned } \\
\text { Enterprise }\end{array}$ & Private & Total \\
\hline 1 & $\begin{array}{l}\text { Medical Center/ } \\
\text { Clinic }\end{array}$ & 0 & 0 & 2 & 0 & 34 & 36 \\
\hline 2 & $\begin{array}{l}\text { General practitioners' } \\
\text { practicing house }\end{array}$ & 0 & 0 & 0 & 0 & 0 & 151 & 151 \\
\hline 3 & $\begin{array}{l}\text { Hospital's Blood } \\
\text { Bank }\end{array}$ & 0 & 0 & 1 & 0 & 0 & 0 & 1 \\
\hline 4 & $\begin{array}{l}\text { Blood Transfusion } \\
\text { Unit }\end{array}$ & 0 & 0 & 0 & 0 & 0 & 1 & 1 \\
\hline
\end{tabular}

Source: Health Profile of Pemalang Regency 2018.

Health logistic in Pemalang Regency is reinforced with 78 units of pharmacy as well. Most of them belong to private ( 75 units), and 3 belong to State-Owned Enterprise. There are 25 drug stores in Pemalang Regency, all of which belong to private. There is 1 unit of health equipment distributor in Pemalang Regency, belonging to private. The detail is presented in Table 6.

Table 6. Pharmaceutical Production and Distribution Media

\begin{tabular}{|c|l|c|c|c|c|c|c|c|}
\hline No & Health Facilities & $\begin{array}{c}\text { Ministry of } \\
\text { Health }\end{array}$ & $\begin{array}{c}\text { Prov. } \\
\text { Gov. }\end{array}$ & $\begin{array}{c}\text { Regency } \\
\text { Gov. }\end{array}$ & $\begin{array}{c}\text { TNI/ } \\
\text { POLRI }\end{array}$ & $\begin{array}{c}\text { State-Owned } \\
\text { Enterprise }\end{array}$ & Private & Total \\
\hline 1 & Pharmacy & 0 & 0 & 0 & 0 & 3 & 75 & 78 \\
\hline 2 & Drug store & 0 & 0 & 0 & 0 & 0 & 25 & 25 \\
\hline 3 & $\begin{array}{l}\text { Distributor of } \\
\text { health equipment }\end{array}$ & 0 & 0 & 0 & 0 & 0 & 1 & 1 \\
\hline
\end{tabular}

Source: Health Profile of Pemalang Regency 2018.

The following are human resources in support of this program. It can be seen in Table 7 .

Table 7. Human Resources

\begin{tabular}{l|l} 
Medical personnel & Year
\end{tabular}




\begin{tabular}{|l|c|c|c|}
\hline & 2015 & 2016 & 2017 \\
\hline 1. Specialist Doctor & 60 & 70 & 70 \\
\hline - Endocrinologists & 9 & 9 & 11 \\
\hline - Obstetrician & 9 & 9 & 8 \\
\hline - Paediatrician & 5 & 6 & 7 \\
\hline - Surgical & 7 & 9 & 8 \\
\hline - Neurologists & 2 & 3 & 2 \\
\hline - Ear, nose, and throat specialist & 2 & 3 & 3 \\
\hline - Ophthalmologists & 2 & 2 & 2 \\
\hline - Dermatologists & 1 & 2 & 1 \\
\hline - Lung specialist & 1 & 3 & 3 \\
\hline - Anesthetist & 6 & 7 & 7 \\
\hline - Medical rehabilitation specialist & 1 & 1 & 1 \\
\hline - Clinical pathology specialist & 2 & 2 & 2 \\
\hline - Radiologists & 1 & 1 & 2 \\
\hline - Urologists & 1 & 1 & 2 \\
\hline - Orthopedic specialist & 6 & 6 & 4 \\
\hline - Neurosurgeon & 2 & 2 & 1 \\
\hline - Psychiatrists & 1 & 1 & 2 \\
\hline - A specialist in oral surgery & 2 & 2 & 2 \\
\hline - Heart and blood vessel specialist & - & 1 & 1 \\
\hline 2. General surgeons & 140 & 127 & 137 \\
\hline 3. Dental & 24 & 23 & 26 \\
\hline
\end{tabular}

Source: Health Profile of Pemalang Regency 2018.

\section{Conclusion}

Health logistic in Pemalang Regency is supplied by Public Health Center (Puskesmas) distributed in some regions. There are 25 Puskesmas units in Pemalang Regency. Health Logistic in Pemalang Regency is also fulfilled by Puskesmas, Pustu (subsidiary public health center), and Pusling (mobile public health center). The distribution of health logistic in Pemalang Regency is also reinforced with the presence of integrated service post (Posyandu), integrated building center (Posbindu), and village health center (Puskesdes).

Health Logistic in Pemalang Regency is reinforced with the presence of 8 hospitals. There are 7 general hospitals and 1 special Hospital in Pemalang Regency. It is also reinforced with 36 units of medical center/clinic. In addition, health logistic in Pemalang Regency is reinforced with 78 units of pharmacy.

Recommendation given in this study is that the health logistic should be reinforced in Mawar Iteng Program in Pemalang Regency. It is because the availability of adequate health logistic is expected to encourage the successful program, thereby improving Human Development Index (HDI). This reinforcement of health logistic can be accomplished by reinforcing the healthcare facilities.

\section{References}


[1] A. Widodo, W. Waridin, and K. Maria, “Analisis pengaruh pengeluaran pemerintah Di sektor pendidikan dan kesehatan Terhadap pengentasan kemiskinan melalui Peningkatan pembangunan manusia di Provinsi jawa tengah," J. Din. Ekon. Pembang., vol. 1, no. 1, pp. 1-183, 2011.

[2] R. Maulana and P. A. Bowo, "Pengaruh Pertumbuhan Ekonomi, Pendidikan dan Teknologi terhadap IPM Provinsi di Indonesia 2007-2011,” JEJAK J. Ekon. dan Kebijak., vol. 6, no. 2, 2013.

[3] G. Guswani, "Analisis Pengelolaan Manajemen Logistik Obat di Instalasi Farmasi RSUD Lanto Daeng Pasewang Kabupaten Jeneponto Tahun 2016.” Universitas Islam Negeri Alauddin MAkassar, 2016.

[4] J. Kenedi, D. Lanin, and Z. Agus, “Analisis Pengadaan Alat Kesehatan di Rumah Sakit Umum Daerah Padang Pariaman tahun 2017,” J. Kesehat. Andalas, vol. 7, pp. 9-16, 2018.

[5] R. R. D. Nanda, "Manajemen Pengelolaan Obat di Puskesmas Limapuluh Kota Pekanbaru Tahun 2017," Menara Ilmu, vol. 11, no. 78, 2017.

[6] K. Ginting, S.C.K., Lubis, I., dan Mahalli, "Pembangunan Manusia di Indonesia dan factor-faktor yang mempengaruhinya," Wahana Hijau J. Perenc. dan Pengemb. Wil., vol. 4, no. 1, pp. 17-24, 2008.

[7] N. A. Bhakti, Istiqomah, and Suprapto, "Analisis Faktor-Faktor yang Mempengaruhi Indeks Pembangunan Manusia di Indonesia Periode 2008-2012," EKUITAS (Jurnal Ekon. dan Keuangan), vol. 18, no. 4, pp. 469-542, 2018.

[8] M. A. Rizky, "Pengukuran Kinerja Supply Chain Management Pada PT. Caraka Purnama Abadi Pasuruan dengan Menggunakan Metode Score." Universitas Airlangga, 2012.

[9] H. Febriawati, "Manajemen Logistik Farmasi Rumah Sakit," Yogyakarta Gosyen Publ., 2013.

[10] Lukas and Sari, Manajemen Logistik. Jakarta: PT. Grasindo, 2004. 